\title{
37. CARBONATE DISSOLUTION FACIES OF LATE MIOCENE TO PLEISTOCENE SEDIMENTS FROM LEG 73, SITES 519 AND 520 (SOUTH ATLANTIC)1
}

\author{
Willi Finger, Geologisches Institut, Eidgenössische Technische Hochschule Zürich, CH-8092 Zürich, Switzerland
}

\begin{abstract}
The dissolution facies of 68 sediment samples from Leg 73 were determined by analyzing carbonate content and grain size. All sediments (Miocene to Pleistocene) from Site 519 and the Pliocene sediments from Site 520 were eolytic or oligolytic; that is, they were deposited above the lysocline. Miocene sediments from Site 520 were mesolytic or pleistolytic (deposited below the lysocline).
\end{abstract}

\section{INTRODUCTION}

Hsü and Andrews established five dissolution facies for pelagic sediments (1970). This definition was slightly modified by Violanti et al. (1979), a modification that resulted in the following scheme:

\begin{tabular}{lcc}
\hline \multicolumn{1}{c}{ Facies } & Terrigenous matter & Sand fraction $(>63 \mu \mathrm{m})$ \\
\hline Alytic & \multicolumn{2}{c}{ Idealized sediment only } \\
Eolytic & $<10 \%$ & $>6 \%$ \\
Oligolytic & $<30 \%$ & $<6 \%$ \\
Mesolytic & $30-70 \%$ & Commonly $<1 \%$ \\
Pleistolytic & $>70 \%$ & Commonly $<1 \%$ \\
Hololytic & Abyssal clay devoid of calcium carbonate \\
\hline
\end{tabular}

In other words, the dissolution facies of a sediment can be defined by determining the content of terrigenous clastics (or the $\mathrm{CaCO}_{3}$ content) and the percentage of foraminifers (i.e., the size of the fraction $>63 \mu \mathrm{m}$.) This work was done on sediment samples from Leg 73, Sites 519 and 520, and the results are reported herein. Other parameters that could define a dissolution facies, like the ratio between planktonic and benthic foraminifers, the diversity of the planktonic fauna, and the number of whole tests per gram of fraction $>100 \mu \mathrm{m}$ (e.g., Violanti et al., 1979; Thunell, 1976), have not been investigated.

\section{METHODOLOGY}

Sixty-one samples from Site 519 and eight samples from Site 520 were analyzed. The sub-bottom depths, lithologic units, and ages of the samples are listed in Table 1 . About 5 to $10 \mathrm{~g}$ of each sample were freeze dried. One part of each dried sample, about $1 \mathrm{~g}$, was used for the determination of $\mathrm{CaCO}_{3}$ content. The analysis was done with a Ströhlein Coulomat. The sediment is burned in a $\mathrm{O}_{2}$ current, the resulting $\mathrm{CO}_{2}$ is volumetrically analyzed, and the total carbon content of the sample is printed out. By operating the Coulomat with $\mathrm{N}_{2}$, only the $\mathrm{CO}_{2}$ from the carbonates is measured, because the organic carbon is not oxidized as it is in the $\mathrm{O}_{2}$ current. The difference between the two measurements is equal to the organic carbon content. The sediments of Sites 519 and $\mathbf{5 2 0}$ do not contain a significant amount of organic carbon.

For our purposes, the carbon contents (measured with $\mathrm{N}_{2}$ ) of the samples were multiplied by the stoichiometric factor 8.33 to obtain the

\footnotetext{
${ }^{1}$ Hsï, K. J., LaBrecque, J. L., et al., Init. Repts. DSDP, 73: Washington (U.S. Govt. Printing Office).
}

$\mathrm{CaCO}_{3}$ percentage (see Table 1). The percentage of terrigenous matter is $100 \%$ minus the percentage of $\mathrm{CaCO}_{3}$.

The second part of the dried sample was used for the grain-size analysis. About 3 to $6 \mathrm{~g}$ of each sample were weighed exactly and soaked with $\mathrm{H}_{2} \mathrm{O}_{2}$. After $30 \mathrm{~min}$. the samples were placed in an ultrasonic bath for $30 \mathrm{~s}$. Distilled water was added and the samples were wet sieved through $180 \mu \mathrm{m}, 90 \mu \mathrm{m}$, and $63 \mu \mathrm{m}$ sieves and a filter. The sieve fractions were dried and weighed.

Calculations were made to acquire the weight percentages of the fractions $>180 \mu \mathrm{m}, 90$ to $180 \mu \mathrm{m},>90 \mu \mathrm{m}, 63$ to $90 \mu \mathrm{m},>63 \mu \mathrm{m}$, and the proportions $>90 \mu \mathrm{m} />63 \mu \mathrm{m}$ and $>180 \mu \mathrm{m} />90 \mu \mathrm{m}$ (see Table 1). Graphical representations of the results are shown in Figures 1, 2, and 3.

\section{RESULTS}

All samples of Lithologic Unit 1 of Site 519 are eolytic (see Fig. 1). The foraminiferal sands of Core 4 have very high $>63 \mu \mathrm{m}$ values (more than $70 \%$ ). The foraminifernannofossil oozes still contain more than $10 \%>63 \mu \mathrm{m}$ fraction. The $>90 \mu \mathrm{m} />63 \mu \mathrm{m}$ and $>180 \mu \mathrm{m} />90 \mu \mathrm{m}$ ratios are relatively high, especially those of the foraminiferal sands (see Figs. 2 and 3). The foraminifer-nannofossil oozes of Unit 2 are also eolytic, with $>90 \mu \mathrm{m} />63 \mu \mathrm{m}$ ratios in general between 70 and $90 \%$. Samples 31 and 32 are nannofossil oozes that lie in the oligolytic area (Fig. 1). The diatom nannofossil oozes (Cores 16 and 24) contain sand fractions in the range of an eolytic sediment, with the exception of Sample 41 . The $\mathrm{CaCO}_{3}$ content of these oozes often is below $90 \%$ as a result of the presence of the siliceous tests of the diatoms.

Except for Sample 54, which is a foraminiferal-nannofossil ooze, all the samples from Lithologic Unit 3 are oligolytic nannofossil oozes, with sand fractions between 1 and $6 \%$. The $>90 \mu \mathrm{m} />63 \mu \mathrm{m}$ ratios are between 50 and $80 \%$. Three samples from Site 520 are oligolytic. The nannofossil oozes of Samples 61 and 62 are even close to the eolytic area. Four samples are mesolytic nannofossil clays or marly nannofossil oozes, and one is pleistolytic (see Fig. 1 and Table 1).

\section{DISCUSSION}

The inverse correlation of the two parameters ([1] terrigenous content and [2] weight percentage of the fraction $>63 \mu \mathrm{m}$ ), as stated in Hsü and Andrews (1970), can be confirmed by our investigations. As the sand fraction 
Table $1 . \mathrm{CaCO}_{3}$ content, grain size, and dissolution facies of the samples.

\begin{tabular}{|c|c|c|c|c|c|c|c|c|c|c|c|c|c|c|}
\hline \multirow[b]{2}{*}{ Sample } & \multirow{2}{*}{$\begin{array}{l}\text { Sub-bottom } \\
\text { depth }(\mathrm{cm})\end{array}$} & \multirow{2}{*}{$\begin{array}{c}\text { Core- } \\
\text { Section, } \\
\text { (interval in cm) }\end{array}$} & \multirow{2}{*}{$\begin{array}{l}\text { Carbon } \\
\text { (wt.\%) }\end{array}$} & \multirow{2}{*}{$\begin{array}{l}\mathrm{CaCO}_{3} \\
\text { (wt.\%) }\end{array}$} & \multicolumn{5}{|c|}{ Wt. $\%$ of the fractions } & $>90 \mu \mathrm{m} /$ & $180 \mu \mathrm{m} /$ & Dissolution & Lithologic & \\
\hline & & & & & $>180 \mu \mathrm{m}$ & $90-180 \mu \mathrm{m}$ & $>90 \mu \mathrm{m}$ & $63-90 \mu \mathrm{m}$ & $>63 \mu \mathrm{m}$ & $>63 \mu \mathrm{m}(\%)$ & $>90 \mu \mathrm{m}(\%)$ & facies $^{\mathbf{a}}$ & Unit & Age \\
\hline Site 519 & & & & & & & & & & & & & & \\
\hline 1 & 1,271 & $4-2,140-142$ & 11.13 & 92.75 & 44.7 & 22.5 & 67.2 & 3.9 & 71.1 & 94.5 & 66.5 & $\mathbf{E}$ & & \\
\hline 2 & 1,278 & $4-2,147-149$ & 10.98 & 91.50 & 4.2 & 10.4 & 14.6 & 6.4 & 21.0 & 69.5 & 29.5 & $\mathrm{E}$ & & \\
\hline 3 & 1,300 & $4-3,19-21$ & 11.05 & 92.08 & 52.8 & 23.7 & 76.5 & 3.8 & 80.3 & 95.3 & 69.0 & $\bar{E}$ & & \\
\hline 4 & 1,305 & $4-3,24-26$ & 11.22 & 93.50 & 56.6 & 15.7 & 72.3 & 3.1 & 75.4 & 95.9 & 78.3 & E & & \\
\hline 5 & 1,311 & $4-3,31-33$ & 11.05 & 92.08 & 66.5 & 12.7 & 79.2 & 2.2 & 81.4 & 97.3 & 84.0 & E & & Pleistocene \\
\hline 6 & 1,319 & $4-3,38-40$ & 10.99 & 91.58 & 63.6 & 8.6 & 72.2 & 2.1 & 74.4 & 95.9 & 78.3 & $\mathbf{E}$ & & \\
\hline 7 & 1,324 & $4-3,43-45$ & 11.16 & 93.00 & 57.3 & 12.2 & 69.5 & 4.2 & 73.7 & 94.3 & 82.5 & E & & \\
\hline 8 & 1,329 & $4-3,48-50$ & 11.16 & 93.00 & 62.6 & 7.4 & 70.0 & 2.4 & 72.4 & 96.7 & 89.4 & $\bar{E}$ & 1 & \\
\hline 9 & 1,344 & $4-3,63-65$ & 11.42 & 95.17 & 6.9 & 4.7 & 11.6 & 2.8 & 14.4 & 80.6 & 59.5 & $\mathbf{E}$ & & \\
\hline 10 & 1,779 & $5-2,98-100$ & 10.89 & 90.75 & 6.5 & 4.9 & 11.4 & 3.9 & 15.3 & 74.5 & 57.0 & E & & \\
\hline 11 & 3,370 & $9-2,89-91$ & 11.07 & 92.25 & 4.8 & 4.7 & 9.5 & 2.5 & 12.0 & 79.2 & 50.5 & $\mathbf{E}$ & & \\
\hline 12 & 3,376 & $9-2,96-97$ & 10.89 & 90.75 & 4.5 & 5.8 & 10.3 & 2.4 & 12.7 & 81.1 & 43.7 & E & & \\
\hline 13 & 3,378 & $9-2,98-99$ & 11.16 & 93.00 & 8.3 & 16.3 & 24.6 & 6.2 & 30.8 & 79.9 & 33.7 & E & & \\
\hline 14 & 3,381 & $9-2,101-102$ & 11.08 & 92.33 & 10.2 & 18.8 & 29.0 & 10.8 & 39.8 & 72.9 & 35.2 & E & & \\
\hline 15 & 3,382 & $9-2,102-104$ & 11.07 & 92.25 & 6.2 & 6.1 & 12.3 & 3.3 & 15.6 & 78.9 & 50.4 & E & & \\
\hline 16 & 6,225 & $16-1,55-56$ & 11.01 & 91.75 & 3.8 & 3.7 & 7.5 & 1.9 & 9.4 & 79.8 & 50.7 & E & & \\
\hline 17 & 6,227 & $16-1,57-58$ & 10.95 & 91.25 & 2.5 & 4.1 & 6.6 & 1.9 & 8.5 & 77.7 & 37.9 & E & & \\
\hline 18 & 6,232 & $16-1,62-63$ & 10.12 & 84.33 & 3.4 & 6.0 & 9.4 & 2.8 & 12.2 & 77.1 & 36.2 & E & & \\
\hline 19 & 6,235 & $16-1,65-66$ & 10.43 & 86.92 & 4.3 & 4.5 & 8.8 & 3.2 & 12.0 & 73.3 & 48.9 & E & & \\
\hline 20 & 6,246 & $16-1,75-77$ & 10.99 & 91.58 & 4.0 & 2.7 & 6.7 & 1.4 & 8.1 & 82.7 & 59.7 & E & & \\
\hline 21 & 6,257 & $16-1,87-88$ & 10.90 & 90.83 & 3.7 & 2.4 & 6.1 & 0.9 & 7.0 & 87.1 & 60.7 & E & & \\
\hline 22 & 6,260 & $16-1,90-91$ & 10.83 & 90.25 & 4.1 & 3.0 & 7.1 & 1.6 & 8.7 & 81.6 & 57.8 & E & & \\
\hline 23 & 6,263 & $16-1,93-94$ & 10.38 & 86.50 & 5.1 & 3.1 & 8.2 & 2.0 & 10.2 & 80.4 & 62.2 & E & & \\
\hline 24 & 6,264 & $16-1,94-95$ & 9.20 & 76.67 & 4.5 & 4.0 & 8.5 & 2.1 & 10.6 & 80.2 & 52.9 & $\mathrm{E}$ & & \\
\hline 25 & 6,269 & $16-1,99-100$ & 9.13 & 76.08 & 3.9 & 5.3 & 9.2 & 4.2 & 13.4 & 68.7 & 42.4 & E & & \\
\hline 26 & 6,271 & $16-1,101-102$ & 7.68 & 64.00 & 2.8 & 7.8 & 10.6 & 4.8 & 15.4 & 68.8 & 26.4 & E & & \\
\hline 27 & 6,273 & $16-1,103-104$ & 7.43 & 61.92 & 1.8 & 5.3 & 7.1 & 2.9 & 10.0 & 71.0 & 25.4 & E & & \\
\hline 28 & 6,278 & $16-1,108-109$ & 8.02 & 66.83 & 2.6 & 4.6 & 7.2 & 2.9 & 10.1 & 71.3 & 36.1 & E & & \\
\hline 29 & 6,282 & $16-1,112-113$ & 8.70 & 72.50 & 2.8 & 2.1 & 4.9 & 3.1 & 8.0 & 61.3 & 57.1 & $\mathrm{E}$ & 2 & \\
\hline 30 & 6,286 & $16-1,116-117$ & 10.25 & 85.42 & 4.3 & 3.5 & 7.8 & 1.7 & 9.5 & 82.1 & 55.1 & E & & \\
\hline 31 & 9,502 & $23-2,101-103$ & 11.48 & 95.67 & 2.4 & 1.1 & 3.5 & 0.8 & 4.3 & 81.4 & 68.6 & o & & Pliocene \\
\hline 32 & 9,527 & $23-2,126-128$ & 11.49 & 95.75 & 0.6 & 0.8 & 1.4 & 0.6 & 2.0 & 70.0 & 42.9 & o & & \\
\hline 33 & 9,546 & $23-2,145-147$ & 11.43 & 95.25 & 0.1 & 11.0 & 11.1 & 17.9 & 29.0 & 37.9 & 0.9 & $\mathrm{E}$ & & \\
\hline 34 & 9,549 & $23-2,149-150$ & 11.49 & 95.75 & 4.8 & 31.5 & 36.3 & 8.3 & 44.6 & 81.4 & 13.2 & E & & \\
\hline 35 & 9,557 & $23-3,6-8$ & 11.41 & 95.08 & 29.3 & 15.1 & 44.4 & 4.6 & 49.0 & 90.6 & 66.0 & $\mathrm{E}$ & & \\
\hline 36 & 9,564 & $23-3,14-15$ & 11.36 & 94.67 & 5.5 & 2.7 & 8.2 & 2.0 & 10.2 & 80.4 & 67.1 & E & & \\
\hline 37 & 9,568 & $23-3,18-19$ & 11.52 & 96.00 & 17.9 & 23.3 & 41.2 & 7.0 & 48.2 & 85.5 & 43.5 & E & & \\
\hline 38 & 10,002 & $24-3,12-13$ & 6.51 & 54.25 & 2.4 & 9.7 & 12.1 & 6.2 & 18.3 & 66.1 & 19.8 & $\mathbf{E}$ & & \\
\hline 39 & 10,003 & $24-3,13-14$ & 9.57 & 79.75 & 12.0 & 17.9 & 29.9 & 7.3 & 37.2 & 80.4 & 40.1 & E & & \\
\hline 40 & 10,005 & $24-3,15-16$ & 11.12 & 92.67 & 2.1 & 2.8 & 4.9 & 2.6 & 7.4 & 66.2 & 42.9 & o & & \\
\hline 41 & 10,010 & $24-3,20-21$ & 10.34 & 86.17 & 0.9 & 0.9 & 1.8 & 0.6 & 2.4 & 75.0 & 50.0 & E & & \\
\hline 42 & 10,013 & $24-3,23-24$ & 7.37 & 61.42 & 2.7 & 4.0 & 6.7 & 3.6 & 10.3 & 65.1 & 40.3 & E & & \\
\hline 43 & 10,015 & $24-3,25-26$ & 11.29 & 94.08 & 1.9 & 3.6 & 5.6 & 2.4 & 8.0 & 70.0 & 33.9 & $\mathrm{O}$ & & \\
\hline 44 & 10,636 & $26-1,65-67$ & 11.06 & 92.17 & 0.4 & 0.5 & 0.9 & 0.4 & 1.3 & 69.2 & 44.4 & o & & \\
\hline 45 & 10,682 & $26-1,111-113$ & 10.17 & 84.75 & 0.5 & 0.9 & 1.4 & 1.0 & 2.4 & 58.3 & 35.7 & o & & \\
\hline 46 & 11,242 & $27-2,81-83$ & 9.66 & 80.50 & 0.4 & 0.5 & 0.9 & 0.4 & 1.3 & 69.2 & 44.4 & 0 & & \\
\hline 47 & 11,271 & $27-2,110-112$ & 10.88 & 90.67 & 0.6 & 0.6 & 1.2 & 0.7 & 1.9 & 63.2 & 50.0 & o & & \\
\hline 48 & 11,580 & $28-1,129-131$ & 10.17 & 84.75 & 0.3 & 0.3 & 0.6 & 0.4 & 1.0 & 60.0 & 50.0 & 0 & & \\
\hline 49 & 11,620 & $28-2,19-21$ & 10.59 & 88.25 & 0.3 & 0.4 & 0.7 & 0.5 & 1.2 & 58.3 & 42.9 & $\mathrm{O}$ & & \\
\hline 50 & 11,650 & $28-2,59-61$ & 9.48 & 79.00 & 0.3 & 0.3 & 0.6 & 0.5 & 1.1 & 54.6 & 50.0 & o & & \\
\hline 51 & 12,111 & $29-2,110-112$ & 9.33 & 77.75 & 0.2 & 0.5 & 0.7 & 0.7 & 1.4 & 50.0 & 28.6 & 0 & & \\
\hline 52 & 12,129 & $29-2,128-130$ & 9.78 & 81.50 & 0.3 & 1.7 & 2.0 & 1.6 & 3.6 & 55.6 & 15.0 & o & 3 & \\
\hline 53 & 12,492 & $30-2,51-53$ & 11.09 & 92.42 & 2.0 & 1.4 & 3.4 & 0.9 & 4.3 & 79.1 & 58.8 & 0 & & \\
\hline 54 & 12,500 & $30-2,60-61$ & 11.13 & 92.75 & 3.9 & 4.0 & 7.9 & 2.3 & 10.2 & 77.5 & 49.4 & E & & \\
\hline 55 & 12,556 & $30-2,115-117$ & 10.97 & 91.42 & 0.9 & 1.3 & 2.2 & 0.7 & 2.8 & 78.6 & 40.9 & 0 & & \\
\hline 56 & 12,641 & $30-3,50-52$ & 11.32 & 94.33 & 0.8 & 0.9 & 1.7 & 0.5 & 2.2 & 77.3 & 47.1 & O & & late \\
\hline 57 & 12,781 & $31-1,90-92$ & 11.00 & 91.67 & 2.8 & 3.0 & 5.8 & 1.5 & 7.3 & 79.5 & 48.3 & $\mathrm{E}$ & & Miocene \\
\hline 58 & 12,801 & $31-1,110-112$ & 11.39 & 94.92 & 0.9 & 1.1 & 2.0 & 0.8 & 2.8 & 71.4 & 45.0 & $\mathrm{o}$ & & \\
\hline 59 & 13,004 & $31-3,13-15$ & 11.14 & 92.83 & 2.3 & 1.3 & 3.6 & 0.9 & 4.5 & 80.0 & 63.9 & 0 & & \\
\hline 60 & 13,045 & $31-1,54-56$ & 11.27 & 93.92 & 1.7 & 2.0 & 3.7 & 1.0 & 4.7 & 78.7 & 46.0 & $\mathrm{O}$ & & \\
\hline Site 520 & & & & & & & & & & & & & & \\
\hline 61 & 17,158 & $4-1,107-109$ & 11.26 & 93.83 & 1.1 & 3.0 & 4.1 & 1.5 & 5.6 & 73.2 & 26.8 & 0 & & \\
\hline 62 & 17,163 & $4-1,113-114$ & 10.97 & 91.42 & 1.0 & 2.8 & 3.8 & 1.2 & 5.0 & 79.0 & 26.3 & O & & Pliocene \\
\hline 63 & 25,743 & $9-5,142-144$ & 5.61 & 46.75 & 0.0 & 0.0 & 0.0 & 0.4 & 0.4 & 0.0 & 0.0 & $\mathbf{M}$ & & \\
\hline 64 & 25,747 & $9-5,146-148$ & 10.24 & 85.33 & 0.3 & 0.3 & 0.6 & 0.1 & 0.7 & 71.4 & 60.0 & $\mathrm{O}$ & & \\
\hline 65 & 30,385 & $15-1,34-36$ & 4.14 & 34.50 & 0.0 & 0.2 & 0.2 & 0.5 & 0.7 & 29.6 & 0.0 & M & & \\
\hline 66 & 30,455 & $15-1,104-106$ & 8.12 & 67.67 & 0.0 & 0.3 & 0.3 & 0.6 & 0.9 & 33.3 & 0.0 & $\mathbf{M}$ & 2 & late \\
\hline 67 & 30,538 & $15-2,37-39$ & 3.15 & 26.25 & 0.0 & 0.2 & 0.2 & 0.4 & 0.6 & 33.3 & 0.0 & $\mathbf{P}$ & & Miocene \\
\hline 68 & 30,577 & $15-2,76-78$ & 8.04 & 67.00 & 0.0 & 0.3 & 0.3 & 0.4 & 0.7 & 40.9 & 0.0 & M & & \\
\hline
\end{tabular}

${ }^{\mathrm{a}} \mathrm{E}=$ eolytic, $\mathrm{O}=$ oligolytic, $\mathrm{M}=$ mesolytic, $\mathrm{P}=$ pleistolytic.

decreases as a result of the fragmentation and the preferred dissolution of the foraminiferal tests, the concentration of terrigenous matter in the sediments increases; that is, the percentage of noncarbonates increases.

The only sediments that do not fit the scheme presented in Violanti et al. (1979) are the diatom nannofossil oozes. Therefore these sediments are neglected in the following discussions of the $>90 \mu \mathrm{m} />63 \mu \mathrm{m}$ and $>180 \mu \mathrm{m} />90 \mu \mathrm{m}$ ratios in relation to the noncarbonate content.
The $>90 \mu \mathrm{m} />63 \mu \mathrm{m}$ ratio is regarded as a measure of whole foraminiferal tests in relation to partially fragmented tests. This ratio shows an inverse correlation to the percentage of noncarbonates (Fig. 2). Mesolytic and pleistolytic sediments have the lowest ratios (less than $50 \%$ ). Ratios over $50 \%$ are generally found in the oligolytic and eolytic samples. A not very sharp differentiation can be made between oligolytic (ratios between 50 and $80 \%$ ) and eolytic (ratios between 70 and $95 \%$ ) sediments. 


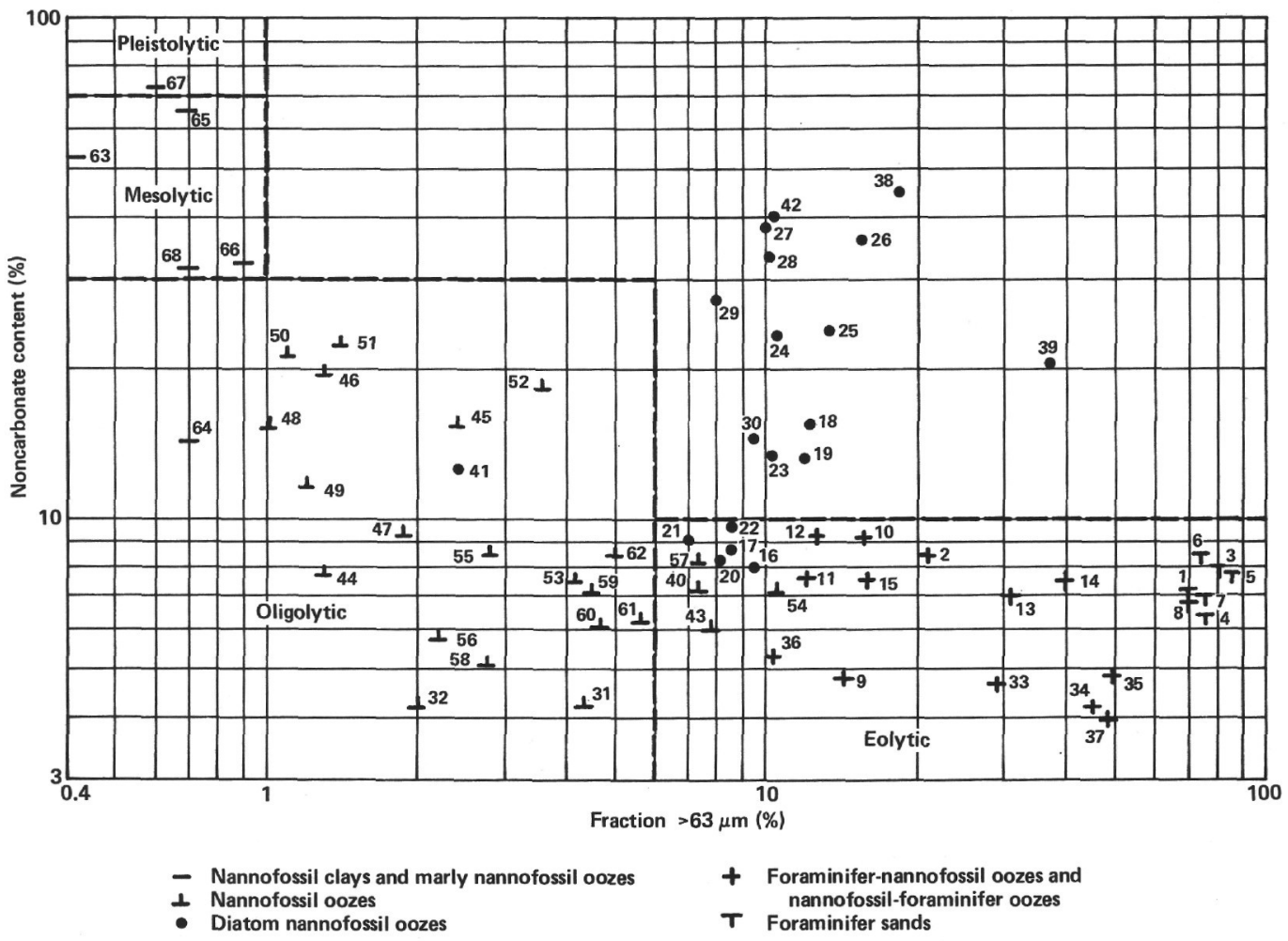

Figure 1. Terrigenous content plotted versus percentage of sand fraction. Areas of dissolution facies as defined by Violanti et al. (1979) are framed. The only sediments that do not fit the scheme are the diatom nannofossil oozes. Sample numbers refer to those in Table 1.

The ratio of whole foraminiferal tests larger than $180 \mu \mathrm{m}$ to those larger than $90 \mu \mathrm{m}$ also shows an inverse correlation to the percentage of noncarbonates (Fig. 3). The trend is not as obvious as that of the $>90 \mu \mathrm{m} /$ $>63 \mu \mathrm{m}$ ratio. Clear limits between the dissolution facies cannot be traced.

\section{CONCLUSIONS}

All except a few samples from Site 519 are eolytic or oligolytic. The sediments must have been deposited above the lysocline at the time of the late Miocene until the Pleistocene. A reconstruction of the bathymetry of Site 519 and the fluctuation of the lysocline during the late Tertiary (adapted from Berger and Winterer, 1974, and Melguen, 1978) confirms that the depth of deposition of Site 519 always was shallower than the depth of the lysocline in the South Atlantic. Although we can observe an increase in dissolution in the late Miocene and the early Pliocene, the reason may be that during this time the deposition depth was about $200 \mathrm{~m}$ closer to the lysocline than in the late Pliocene and the Pleistocene (see Fig. 4). It is understandable that the late Miocene sediments of Site 520 are mesolytic or pleistolytic, be- cause the lysocline was higher than the depth of deposition. The oligolytic samples of Site 520 are from the Pliocene when the lysocline was at a depth of approximately $4200 \mathrm{~m}$, that is, $200 \mathrm{~m}$ deeper than the place of deposition.

\section{REFERENCES}

Berger, W. H., and Winterer E. L., 1974. Plate statigraphy and fluctuating carbonate line. IAS Spec. Publ. No. 1, pp. 11-48.

Hsü, K. J., and Andrews, J. E., 1970. History of South Atlantic Basin. In Maxwell, A. E., Von Herzen, R. P., et al., Init. Repts. DSDP, 3: Washington (U.S. Govt. Printing Office), 464-467.

Melguen M., 1978. Facies evolution, carbonate dissolution cycles in sediments from the eastern South Atlantic (DSDP Leg 40) since the Early Cretaceous. In Bolli, H. M., Ryan, W. B. F., et al., Init. Repts. DSDP, 40: Washington (U.S. Govt. Printing Office), 981-1024.

Violanti, D., Premoli Silva, I., Cita, M. B., Kersey, D., and Hsü K. J., 1979. Quantitative characterization of carbonate dissolution facies of the Atlantic Tertiary sediments. An attempt. Riv. Ital. Paleontol., 85:517-548.

Thunell, R. C., 1976. Optimum indices of calcium carbonate dissolution in deep-sea sediments. Geology, 4:525-528.

Date of Initial Receipt: August 31, 1982 


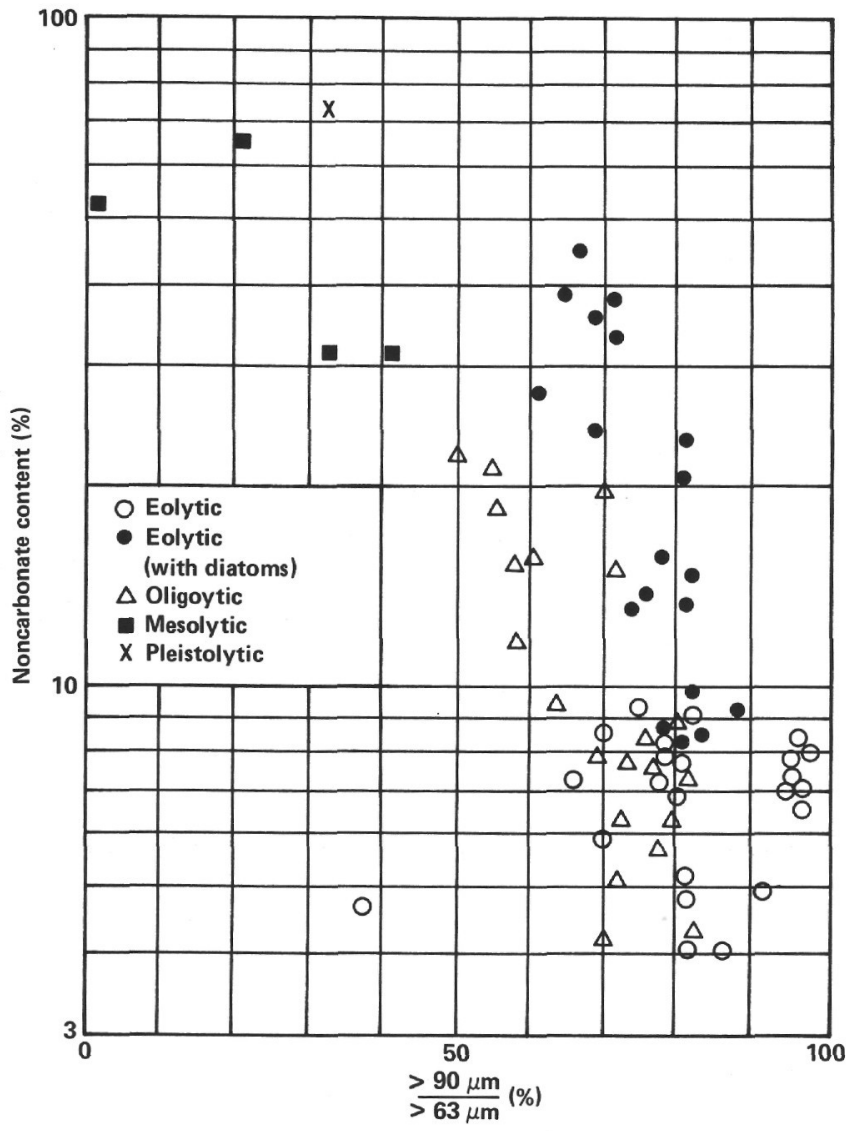

Figure 2. Terrigenous content plotted versus the ratio $>90 \mu \mathrm{m} /$ $>63 \mu \mathrm{m}$. The samples are designated with symbols that indicate their dissolution facies. Sites 519 and 520 .

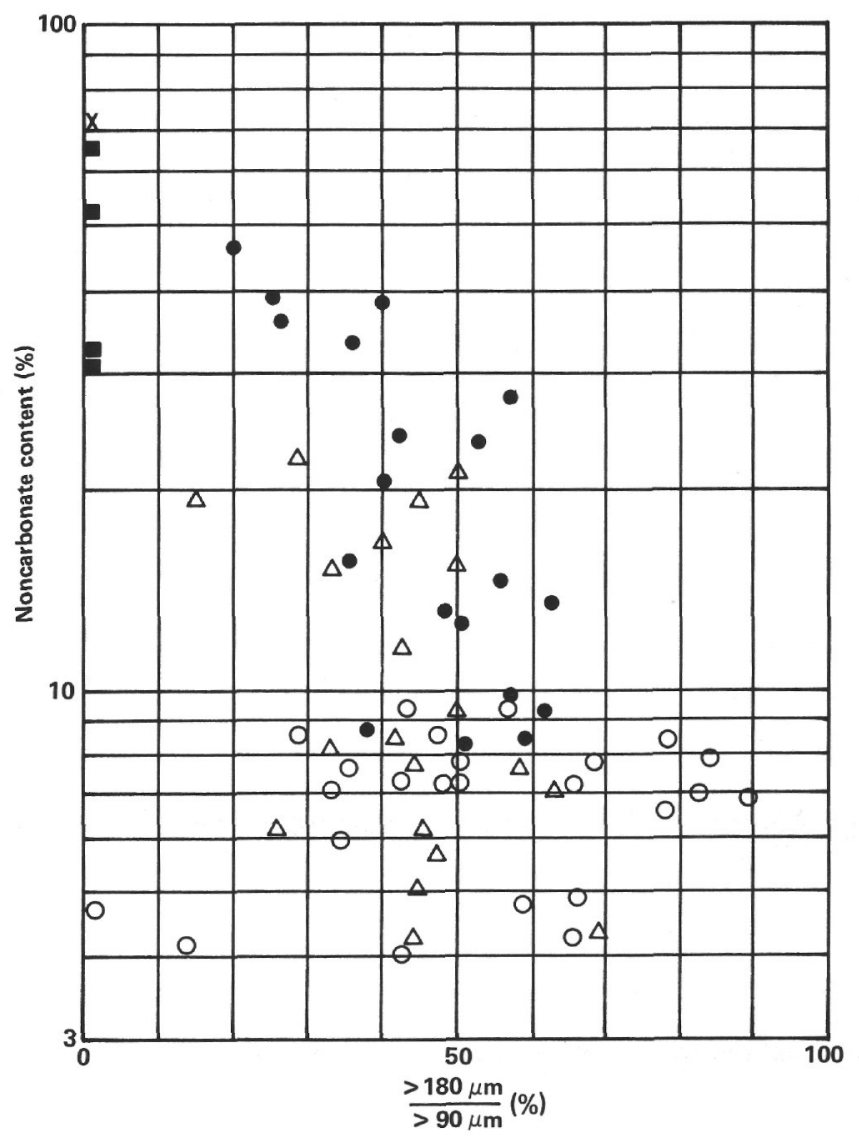

Figure 3. Terrigenous content plotted versus the ratio $>180 \mu \mathrm{m} />90$ $\mu \mathrm{m}$. Symbols as in Fig. 2. Sites 519 and 520 . 


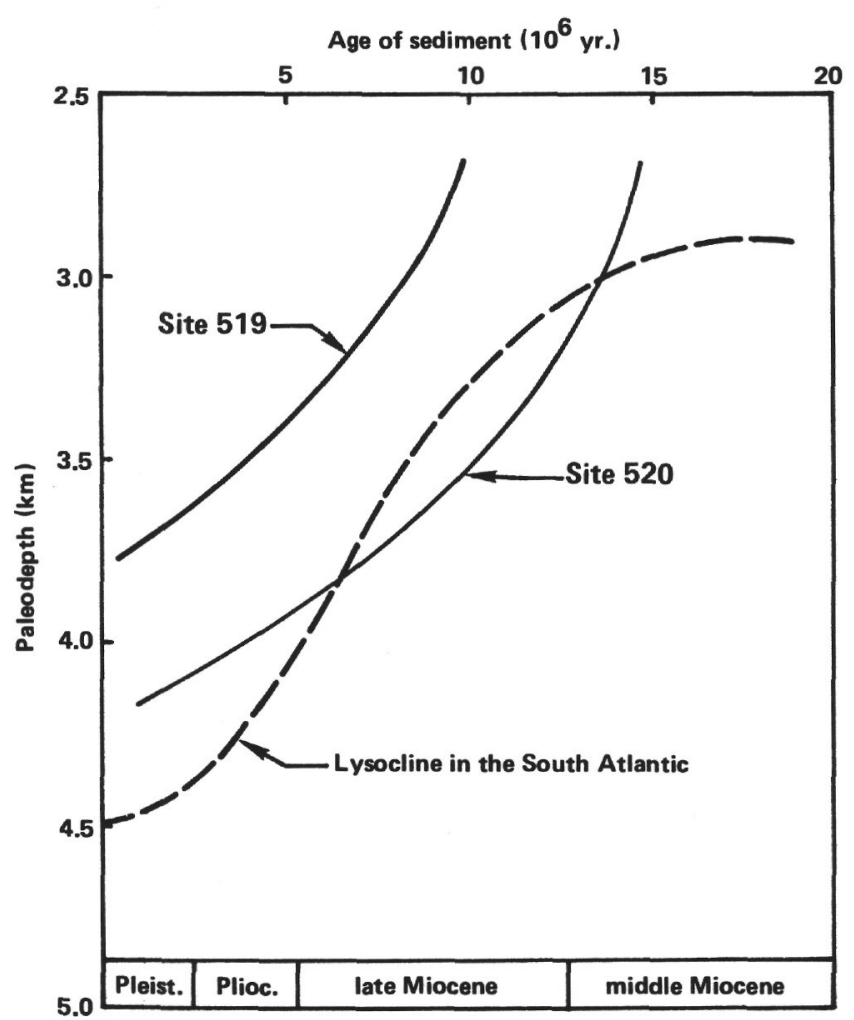

Figure 4. Bathymetry of Sites 519 and 520 (reconstructed using the backtracking method of Berger and Winterer, 1974) and fluctuation of the lysocline in the South Atlantic during the late Tertiary. CCD fluctuation curves for the South Atlantic are given in Berger and Winterer (1974) and Melguen (1978). The lysocline curve in this figure is about $500 \mathrm{~m}$ higher than the CCD curves. Data from Violanti et al. (1979) were utilized in addition to data from this study to reconstruct the lysocline curve. 